\title{
Spleen Size in Chhattisgarhi Adult Population with Relation to Age using Ultrasonography: A Cross-sectional Study
}

\section{ABSTRACT}

Introduction: Spleen, a vital organ of reticuloendothelial system, which helps in degradation of old red blood cells and secretes properdin, tuftsin and immunoglobulin-G. Spleen known to show variation in shape and size with respect to age, sex, height, weight and ethnicity. Ultrasonography is a non magnetic radiation, easily performed and cost-effective diagnostic procedure which can be used for accurate measurement of spleen.

Aim: To evaluate and correlate splenic dimensions by Ultrasonography (USG) in Chhattisgarh population with respect to age.

Materials and Methods: This cross-sectional study was conducted over a period of one year, from August 2015 to July 2016 in the Departments of Anatomy and Radiodiagnosis at Pt. Jawahar Lal Nehru Memorial (Pt. JNM) Medical College, Raipur, India. A total of 400 subjects were recruited for study, of which 239 were females and 161 were males. The subjects were selected amongst the adult patients, in the age groups of 25-60 years, who had come for abdominal USG. Spleen length, breadth and thickness of these were evaluated using USG. Descriptive analysis was carried out using Microsoft (MS) Excel version 2010 and Statistical Package for the Social Sciences (SPSS) version 23.0 was used to derive mean, standard and Pearson's correlation coefficient (r). Statistical significance was considered at $\mathrm{p}$-value $<0.05$.

Results: A total of 400 subjects were studied with a mean age of $39.23 \pm 10.03$ years. Spleen length, breadth and thickness in age groups $25-30$ years were $95.34 \pm 8.73 \mathrm{~mm}, 49.42 \pm 9.19 \mathrm{~mm}$ and $34.93 \pm 4.62 \mathrm{~mm}$, in age group $31-40$ years was $92.25 \pm 7.13 \mathrm{~mm}$, $45.95 \pm 7.86 \mathrm{~mm}$ and $33.9 \pm 3.88 \mathrm{~mm}$, in age group $41-50$ years was $90.7 \pm 7.69 \mathrm{~mm}, 45.01 \pm 7.31 \mathrm{~mm}$ and $33.5 \pm 3.99 \mathrm{~mm}$ and in $51-$ 60 years was $88.39 \pm 5.25 \mathrm{~mm}, 41.39 \pm 6.64 \mathrm{~mm}$ and $27.67 \pm 2.8 \mathrm{~mm}$ was noted in females. Whereas in males, in age group 25-30 years was $105.43 \pm 10.42 \mathrm{~mm}, 53.87 \pm 8.01 \mathrm{~mm}$ and $41.56 \pm 6.16 \mathrm{~mm}$, in age group $31-40$ years was $101.8 \pm 7.66 \mathrm{~mm}, 48.73 \pm 6.1 \mathrm{~mm}$ and $37.65 \pm 4.27 \mathrm{~mm}$, in age group $41-50$ years was $98.48 \pm 7.03 \mathrm{~mm}$, $45.81 \pm 6.14 \mathrm{~mm}$ and $36.16 \pm 3.98 \mathrm{~mm}$ and in age group 5160 years was $94.38 \pm 7.09 \mathrm{~mm}, 42 \pm 5.94 \mathrm{~mm}$ and $34.3 \pm 4.46 \mathrm{~mm}$, respectively was observed.

Conclusion: Spleen length, breadth and thickness were observed to decrease in size with increase in age, of which spleen breadth in males showed a moderately significant negative correlation $(r=-0.451)$ with age.

Keywords: Red blood cells, Reticulo-endothelial system, Splenic dimensions

\section{INTRODUCTION}

Spleen is an integral organ of the reticulo-endothelial system of human body. It is responsible for removal of old and deformed red blood cells and secretion of properdin, tuftsin and immunoglobulin-G [1]. Spleen varies in size according to sex, height, weight, age and ethnicity [2-5]. Hence, it becomes important to evaluate the size of spleen and correlate it with these variables.

Spleen size can be very easily assessed by palpation. As spleen is physiologically not palpable, therefore, a palpable spleen can apprise us of splenomegaly, but some studies suggest that not always a palpable spleen is splenomegaly [6]. Also, the exact size of the spleen cannot be evaluated using palpation.

Computerised Tomography (CT) scan and Magnetic Resonance Imaging (MRI) although very accurate, are not practical for evaluation of size of spleen, unless warranted. Because of the highly expensive procedural cost of both CT scan and MRI, and side-effects of radiation exposure in CT scan, both these modalities of investigation are not feasible [7-10]

The USG, thereby, is one such diagnostic tool which is relatively cheap and accurate [11-14]. Moreover, USG machines are widely in practice and are available at almost all levels of healthcare system.

The present study was aimed to correlate all the dimensions of spleen, i.e., spleen length, spleen breadth and spleen thickness with age in male and female subjects in Chhattisgarhi population, as no similar study has been performed previously in this region.

\section{MATERIALS AND METHODS}

This cross-sectional study was conducted over a period of one year, from August 2015 to July 2016 in the Department of Anatomy and Radiodiagnosis at Pt. JNM Medical College, Raipur. After ethical approval from the Institute Scientific Committee, a total of 400 subjects were recruited for study, of which 239 were females and 161 were males. The sample size had been calculated by statistical committee, for the facilitation of the research project.

Inclusion criteria: Subjects in an age range of 25-60 years, who were advised abdominal USG and gave their consent for the study were included. It was made sure that they were domicile holder residents of Chhattisgarh, by cross checking it with Aadhaar/Ration card/Below Poverty Line (BPL) card.

Exclusion criteria: Gravid females or patients with any diseases related to spleen, any haemoglobinopathy, any lymphoproliferative disorder, history of splenectomy or any lesion on the skin over the spleen were excluded from the study.

Once history and examination was over, these subjects were asked to sign a hand written proforma, as a proof of consent for examination. They were explained the investigation procedure. Thereafter, asked to lie down on the examination table in right lateral decubitus position. Scanning was done using a $3.5 \mathrm{MHz}$ probe along the anterior, mid and posterior axillary line at the level of nine to eleven ribs. Repeated measurements were made through hilum of spleen, which served as a reference point throughout the study $[15,16]$. 
Splenic length, defined as the maximum distance between the dome of the spleen and the splenic tip, measured on the longitudinal section. Splenic width defined as the maximum distance between the medial and lateral borders of the spleen, measured on a plane perpendicular to the length. Transverse scans were obtained with the transducer rotated through $90^{\circ}$. Splenic thickness was defined as the maximum antero-posterior dimension was measured on the transverse section. Each dimension, rescanned and recorded three different times to the nearest millimetre and the mean value obtained for accuracy of result [17]. Throughout the entire period of study, the observations were made by four different observers.

\section{STATISTICAL ANALYSIS}

Descriptive analysis was carried out using MS Excel 2010 version and SPSS version 22.0 (2013) in which mean, standard and Pearson's correlation coefficient $(r)$ and $p$-value were calculated. A $\mathrm{p}$-value $<0.05$ was considered statistically significant.

\section{RESULTS}

The total number of subjects included in the study were 400 with a mean age of $39.23 \pm 10.03$ years. The mean age of females who underwent the study was $38.47 \pm 10.04$ years, whereas in males it was $40.35 \pm 9.96$ years. The mean values of splenic length, breadth and thickness in females according to age are shown in [Table/Fig-1]. Pearson's correlation coefficient ( $r$ ) of age in females with spleen length was $(r=-0.275, p<0.001)$, spleen breadth was $(r=-0.283$, $p<0.001)$ and spleen thickness was $(r=-0.371, p<0.001)$. Whereas, in males, the mean values of splenic dimensions are shown in [Table/ Fig-2]. Pearson's correlation coefficient $(r)$ of age in males with spleen length was $(r=-0.368, p<0.001)$, spleen breadth was $(r=-0.451$, $p<0.001)$ and spleen thickness was $(r=-0.393, p<0.001)$.

\begin{tabular}{|c|c|c|c|c|}
\hline $\begin{array}{l}\text { Age }(\text { Mean } \\
\text { age }=38.47 \pm 10.04 \\
\text { years) }\end{array}$ & $\begin{array}{l}\text { No. of } \\
\text { cases } \\
(n=239)\end{array}$ & $\begin{array}{l}\text { Spleen } \\
\text { length } \\
(\mathrm{mm}) \pm S D\end{array}$ & $\begin{array}{c}\text { Spleen } \\
\text { breadth } \\
(\mathrm{mm}) \pm S D\end{array}$ & $\begin{array}{l}\text { Spleen } \\
\text { thickness } \\
(\mathrm{mm}) \pm \mathrm{SD}\end{array}$ \\
\hline $25-30 y$ & 75 & $95.34 \pm 8.73$ & $49.42 \pm 9.19$ & $34.93 \pm 4.62$ \\
\hline $31-40 y$ & 71 & $92.25 \pm 7.13$ & $45.95 \pm 7.86$ & $33.9 \pm 3.88$ \\
\hline $41-50 y$ & 65 & $90.7 \pm 7.69$ & $45.01 \pm 7.31$ & $33.5 \pm 3.99$ \\
\hline $51-60 y$ & 28 & $88.39 \pm 5.25$ & $41.39 \pm 6.64$ & $27.67 \pm 2.8$ \\
\hline
\end{tabular}

100

80

60

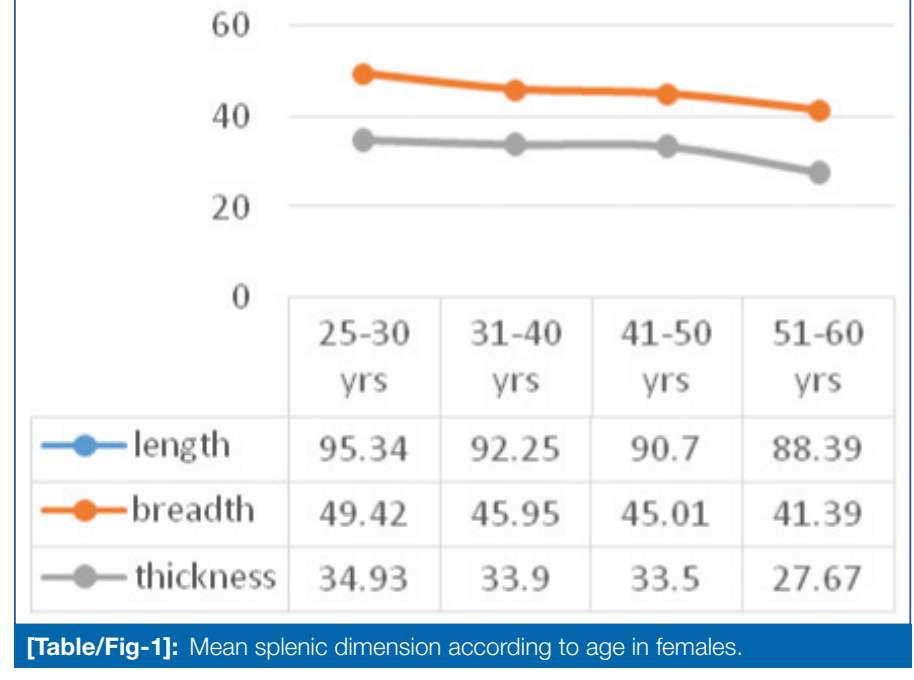

\section{DISCUSSION}

Due to its important role in the haemopoietic system of the human body, estimation of size of spleen becomes an important mode in order to evaluate its proper functioning [18]. In order to evaluate

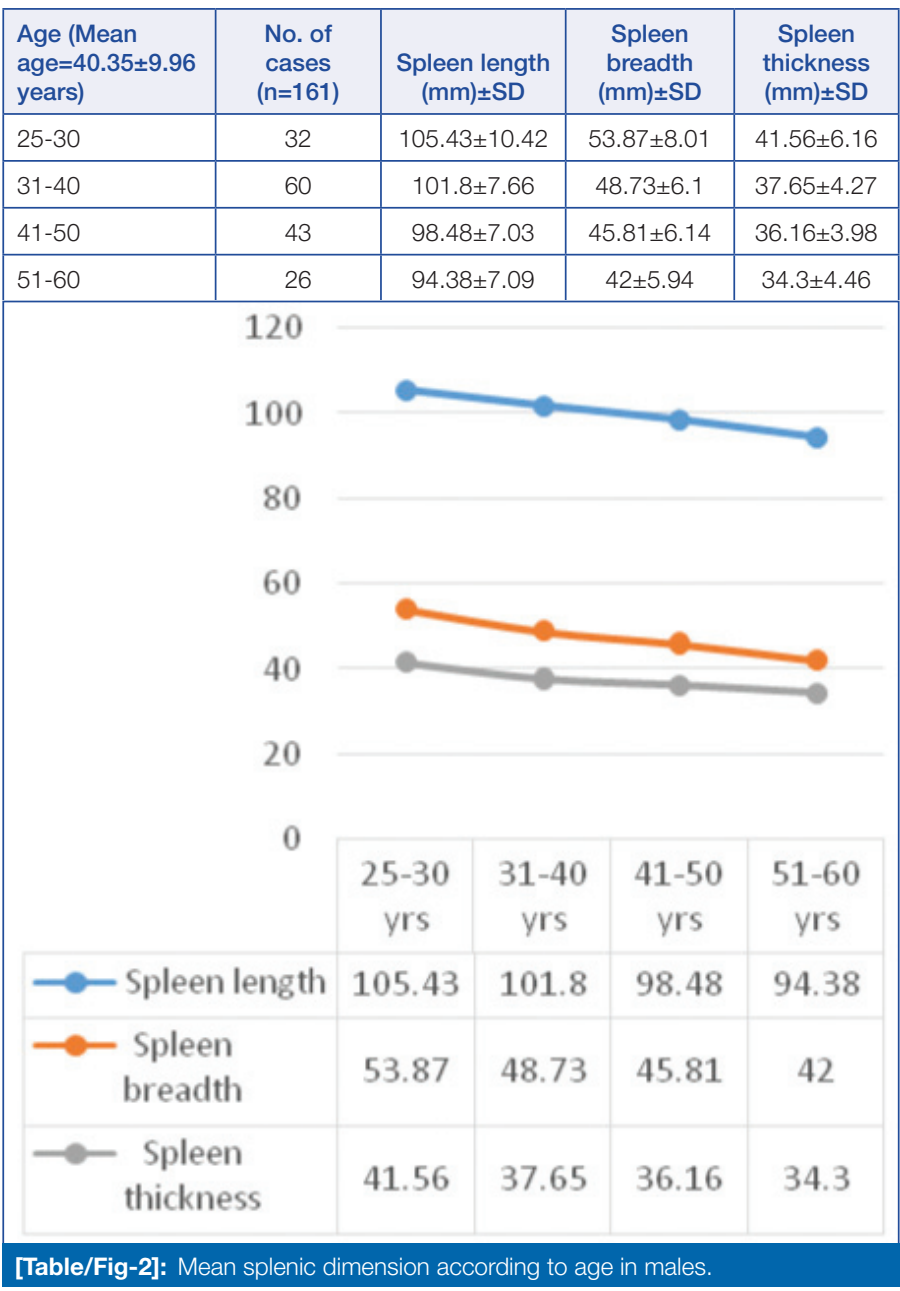

size of spleen, researchers from time to time have studied spleen in cadaver. Some researchers have also correlated spleen size and volume observed in cadaver with age, sex, body height, weight, BMI and Body Surface Area (BSA). Chowdhury Al et al., noted average spleen volume to be $75.27 \pm 3.78 \mathrm{~mL}$ in males and $60.51 \pm 4.90 \mathrm{~mL}$ in females, which increased with age during childhood and adolescence remains stable in young adult and declined in older age groups [19]. Mohammadi $S$ et al., noted the mean values of the spleen length, width, thickness, notch, weight and index in the cadavers which were $11.32 \pm 3.10 \mathrm{~cm}, 8.05 \pm 2.35 \mathrm{~cm}, 20.12 \pm 9.21$ $\mathrm{mm}, 0.84 \pm 1.35,123.87 \pm 82.46 \mathrm{~g}$, and $2.01 \pm 1.40$, respectively [20]. Caglar $\vee$ et al., noted the splenic dimensions in adult autopsies to be $11.3 \pm 1.1 \mathrm{~cm}$ long, $3.8 \pm 1 \mathrm{~cm}$ thick and $6 \pm 0.8 \mathrm{~cm}$ wide, and found a strong correlation with body height, weight, BMI, and BSA [21].

Many researchers have made the use of CT scans in their effort to evaluate and correlate size of spleen with age of participants. Kaneko $\mathrm{J}$ et al., observed the mean volume of the spleen to be $112 \mathrm{cc}$, ranging from 32-209 cc using CT scan in 150 individuals. The spleen volume significantly correlated with age $(R=0.36, p=0.0002)$, but not with body weight or surface area [22]. Srisajjakul $S$ et al., noted the average splenic volume to be $124.1 \pm 51.8 \mathrm{~cm}^{3}$, ranging from 27.60 $430.85 \mathrm{~cm}^{3}$ with a significant correlation with age, height, weight and BMl (age: $r=-0.151, p<0.001$; height: $r=0.187, p<0.001$; weight: $r=0.248, p<0.001$ and BMI: $r=0.159, p<0.05$ ) [23]. A CT based study, by Harris $A$ et al., observed average splenic volume of 230 subjects to be $127.4 \pm 62.9 \mathrm{~cm}^{3}$, ranging from 22 to $417 \mathrm{~cm}^{3}$ [24]. Prassopoulos $P$ et al., noted the mean splenic volume to be $214.6 \mathrm{~cm}^{3}$ with a range from 107.2-314.5 $\mathrm{cm}^{3}$, using CT scan in 140 patients [25]. In the past, researchers have also used to study and analyse splenic dimensions and age with the help of USG, but in children [26-28].

This study was undertaken to evaluate and correlate splenic dimensions with age of participants. In this study, a decrease in all the dimensions of spleen with increasing age, in both males and females, was noted. Using Pearson's formula, correlation coefficient $(r)$ of 


\begin{tabular}{|c|c|c|c|c|c|c|c|c|}
\hline Spleen dimensions & $\begin{array}{l}\text { Age group } \\
\text { (in years) }\end{array}$ & $\begin{array}{l}\text { Present study } \\
\qquad(\mathrm{n}=239)^{\alpha}\end{array}$ & $\begin{array}{c}\text { Gujarat } \\
(n=250)^{\beta}[29]\end{array}$ & $\begin{array}{l}\text { North India } \\
(n=80)^{\beta}[30]\end{array}$ & $\begin{array}{c}\text { Tripura } \\
(n=57)^{\circ} \circ[31]\end{array}$ & $\begin{array}{c}\text { Nepal } \\
(n=160)^{\delta}[32]\end{array}$ & $\begin{array}{l}\text { Bangladesh } \\
(n=84)^{x}[33]\end{array}$ & $\begin{array}{c}\text { Pakistan } \\
(\mathrm{n}=251)^{y}[34]\end{array}$ \\
\hline \multirow{5}{*}{ Spleen length (mm) } & Age group I & $95.34 \pm 8.73$ & $93.80 \pm 11.25$ & $97.09 \pm 16.16$ & $86.7 \pm 8.5$ & $98.3 \pm 5.3$ & $\sim$ & $\sim$ \\
\hline & Age group II & $92.25 \pm 7.13$ & $95.74 \pm 9.86$ & $94.69 \pm 13.67$ & $85.5 \pm 9.3$ & $95.8 \pm 5.8$ & $\sim$ & $\sim$ \\
\hline & Age group III & $90.7 \pm 7.69$ & $92.88 \pm 11.27$ & $92.88 \pm 12.77$ & $92.1 \pm 6.8$ & $92.0 \pm 6.4$ & $\sim$ & $\sim$ \\
\hline & Age group IV & $88.39 \pm 5.25$ & $92.41 \pm 11.83$ & $85.06 \pm 10.09$ & $93.0 \pm 9.1$ & $88.0 \pm 3.6$ & $\sim$ & $\sim$ \\
\hline & Average & $92.35 \pm 7.98$ & $93.6 \pm 11.0$ & $\sim$ & $87.2 \pm 8.9$ & $\sim$ & $76.0 \pm 10.0$ & $96.1 \pm 16.9$ \\
\hline \multirow{5}{*}{ Spleen breadth (mm) } & Age group I & $49.42 \pm 9.19$ & $41.74 \pm 6.82$ & $47.27 \pm 13.05$ & $\sim$ & $\sim$ & $\sim$ & $\sim$ \\
\hline & Age group II & $45.95 \pm 7.86$ & $43.32 \pm 7.85$ & $43.09 \pm 8.33$ & $\sim$ & $\sim$ & $\sim$ & $\sim$ \\
\hline & Age group III & $45.01 \pm 7.31$ & $41.38 \pm 11.27$ & $44.54 \pm 11.46$ & $\sim$ & $\sim$ & $\sim$ & $\sim$ \\
\hline & Age group IV & $41.39 \pm 6.64$ & $40.78 \pm 6.93$ & $38.65 \pm 6.90$ & $\sim$ & $\sim$ & $\sim$ & $\sim$ \\
\hline & Average & $46.25 \pm 8.43$ & $\sim$ & $\sim$ & $\sim$ & $\sim$ & $60.5 \pm 11.9$ & $\sim$ \\
\hline \multirow{5}{*}{ Spleen thickness (mm) } & Age group I & $34.93 \pm 4.62$ & $32.24 \pm 6.06$ & $35.45 \pm 7.50$ & $\sim$ & $4.1 \pm 0.5$ & $\sim$ & $\sim$ \\
\hline & Age group II & $33.9 \pm 3.88$ & $33.34 \pm 6.45$ & $34.37 \pm 6.77$ & $\sim$ & $4.05 \pm 0.58$ & $\sim$ & $\sim$ \\
\hline & Age group III & $33.5 \pm 3.99$ & $33.52 \pm 7.27$ & $34.87 \pm 5.60$ & $\sim$ & $3.43 \pm 0.38$ & $\sim$ & $\sim$ \\
\hline & Age group IV & $27.67 \pm 2.8$ & $32.52 \pm 5.64$ & $30.90 \pm 5.58$ & $\sim$ & $3.0 \pm 0.36$ & $\sim$ & $\sim$ \\
\hline & Average & $33.38 \pm 4.59$ & $\sim$ & $\sim$ & $\sim$ & $\sim$ & $36.3 \pm 7.5$ & $\sim$ \\
\hline
\end{tabular}

[Table/Fig-3]: Comparison of splenic dimensions in females in various studies.

$\alpha=$ Age groups I-IV are 25-30, 31-40, 41-50, 51-60 years respectively; $\beta=$ Age groups I-IV are 21-30, 31-40, 41-50, 51-60 years respectively; $\delta=$ Age groups I-IV are 15-30, 31-45, 46-60, 61-75 years respectively; ${ }^{\circ}=75+$ years age group (not included in table); Range $\chi=(21-80$ years) $\gamma=(15-87$ years)

\begin{tabular}{|c|c|c|c|c|c|c|c|c|}
\hline Spleen dimensions & $\begin{array}{r}\text { Age group } \\
\text { (in years) }\end{array}$ & $\begin{array}{l}\text { Present study } \\
\quad(n=161)^{\alpha}\end{array}$ & $\begin{array}{c}\text { Guajarat } \\
(\mathrm{n}=250)^{\beta}[29]\end{array}$ & $\begin{array}{l}\text { North India } \\
(\mathrm{n}=80)^{\beta}[30]\end{array}$ & $\begin{array}{c}\text { Tripura } \\
(\mathrm{n}=89)^{\delta \circ}[31]\end{array}$ & $\begin{array}{c}\text { Nepal } \\
(\mathrm{n}=160)^{8}[32]\end{array}$ & $\begin{array}{l}\text { Bangladesh } \\
(\mathrm{n}=84)^{\mathrm{x}}[33]\end{array}$ & $\begin{array}{c}\text { Pakistan } \\
(\mathrm{n}=276)^{y}[34]\end{array}$ \\
\hline \multirow{5}{*}{ Spleen length $(\mathrm{mm})$} & Age group I & $105.43 \pm 10.42$ & $100.84 \pm 9.83$ & $107.24 \pm 13.18$ & $93.5 \pm 11.8$ & $100.7 \pm 7.0$ & $\sim$ & $\sim$ \\
\hline & Age group II & $101.8 \pm 7.66$ & $99.97 \pm 10.18$ & $103.50 \pm 10.12$ & $90.4 \pm 18.4$ & $101.0 \pm 5.4$ & $\sim$ & $\sim$ \\
\hline & Age group III & $98.48 \pm 7.03$ & $99.38 \pm 7.39$ & $100.23 \pm 14.11$ & $91.3 \pm 11.5$ & $95.0 \pm 7.0$ & $\sim$ & $\sim$ \\
\hline & Age group IV & $94.38 \pm 7.09$ & $94.82 \pm 12.12$ & $87.85 \pm 12.15$ & $85.1 \pm 16.2$ & $90.0 \pm 4.3$ & $\sim$ & $\sim$ \\
\hline & Average & $100.44 \pm 8.80$ & $98.7 \pm 9.8$ & $\sim$ & $88.5 \pm 15.4$ & $\sim$ & $86.6 \pm 7.4$ & $101.3 \pm 17.7$ \\
\hline \multirow{5}{*}{ Spleen breadth (mm) } & Age group I & $53.87 \pm 8.01$ & $45.75 \pm 7.12$ & $55.07 \pm 10.97$ & $\sim$ & $\sim$ & $\sim$ & $\sim$ \\
\hline & Age group II & $48.73 \pm 6.1$ & $44.64 \pm 6.67$ & $46.53 \pm 6.77$ & $\sim$ & $\sim$ & $\sim$ & $\sim$ \\
\hline & Age group III & $45.81 \pm 6.14$ & $45.90 \pm 7.39$ & $49.00 \pm 18.80$ & $\sim$ & $\sim$ & $\sim$ & $\sim$ \\
\hline & Age group IV & $42 \pm 5.94$ & $42.79 \pm 7.60$ & $42.64 \pm 7.26$ & $\sim$ & $\sim$ & $\sim$ & $\sim$ \\
\hline & Average & $47.88 \pm 7.52$ & $\sim$ & $\sim$ & $\sim$ & $\sim$ & $76.7 \pm 3.5$ & $\sim$ \\
\hline \multirow{5}{*}{$\begin{array}{l}\text { Spleen thickness } \\
(\mathrm{mm})\end{array}$} & Age group I & $41.56 \pm 6.16$ & $35.3 \pm 6.80$ & $39.60 \pm 7.51$ & $\sim$ & $40.6 \pm 4.7$ & $\sim$ & $\sim$ \\
\hline & Age group II & $37.65 \pm 4.27$ & $34.25 \pm 6.16$ & $38.79 \pm 5.30$ & $\sim$ & $37.8 \pm 4.8$ & $\sim$ & $\sim$ \\
\hline & Age group III & $36.16 \pm 3.98$ & $35.86 \pm 6.78$ & $38.93 \pm 5.50$ & $\sim$ & $33.8 \pm 3.5$ & $\sim$ & $\sim$ \\
\hline & Age group IV & $34.3 \pm 4.46$ & $34.05 \pm 6.37$ & $34.41 \pm 6.47$ & $\sim$ & $22.9 \pm 2.3$ & $\sim$ & $\sim$ \\
\hline & Average & $37.49 \pm 5.22$ & $\sim$ & $\sim$ & $\sim$ & $\sim$ & $40.1 \pm 3.4$ & $\sim$ \\
\hline
\end{tabular}

[Table/Fig-4]: Comparison of splenic dimensions in males in various studies.

$\alpha=$ Age groups I-IV are 25-30, 31-40, 41-50, 51-60 years respectively; $\beta=$ Age groups I-IV are 21-30, 31-40, 41-50, 51-60 years respectively; $\delta=$ Age groups I-IV are 15-30, 31-45, 46-60, 61-75 years respectively; ${ }^{\circ}=75+$ years age group (not included in table); Range $\chi=(21-80$ years) $\gamma=(15-87$ years)

subject age with spleen length was $(r=-0.275)$, spleen breadth was $(r=-0.283)$ and spleen thickness was $(r=-0.371)$, in females; and spleen length was $(r=-0.368)$, spleen breadth was $(r=-0.451)$ and spleen thickness was ( $r=-0.393)$, in males. The negative correlation coefficient shows a decrease in splenic dimensions with increase in age.

In the present study, spleen length in both, females and males, decreased at a slow and constant rate with growing age. As shown in the [Table/Fig-3,4], this finding was similar to a study conducted on Gujarati population [29]. Although it differed with a study on north Indian population and a study on Chinese population, in which they observed that splenic length decreased slowly upto the age of 50 years after which there was a rapid decrease in spleen length [30,32]. Similar findings were also noted in studies conducted in Tripura, Nepal and Bangladesh [32,33,34]. Whereas, a study conducted in Pakistan observed weak positive correlation of spleen length with age [35].

Spleen breadth, in females, showed a slow decrease upto the age of 40 years, thereafter it is constant upto 50 years, after which there was a slow decrease noted again, in the present study, whereas in males, spleen breadth showed a constant but slow decrease with increasing age. These findings were similar to the findings of study in north Indian population [30].

In the current study, spleen thickness, in females, was constant upto the age of 50 years, beyond which, there was a steep decrease noted. This finding is very similar to the studies conducted on north Indian population and Gujarati population [29, 30]. However, in males, there was a constant decrease observed with increasing age.

\section{Limitation(s)}

Although, this study did not involve paediatric and geriatric age groups, which was it's limitation, it still can serve as a database for further researches on adult spleen, in the region of central India, which is endemic to diseases like Sickle Cell Anaemia, Thalassemia and Malaria, which can affect the size of spleen.

\section{CONCLUSION(S)}

Spleen size often varies in various physiological and pathological conditions. Hence, estimation of size according to age is necessary in order to avoid incorrect assessment, which may lead to false diagnosis. The present study shows a decline in all the splenic dimensions, i.e., splenic length, breadth and thickness, in both 
female and male population of Chhattisgarh. Spleen breadth in males showed a moderately (0.451) negative correlation with age, while spleen length and thickness in males and spleen length, breadth and thickness in females showed low negative correlation with age.

\section{Acknowledgement}

The authors would like to sincerely thank the subjects who agreed to participate in the study. They would also like to acknowledge the nursing and cleaning staff of Dr B R Ambedkar Hospital, who manged the participants and the study area which helped them to conduct the study smoothly. No funding was received for conducting this study.

\section{REFERENCES}

[1] Vasilescu C. Functions of the spleen and their evaluation. In: The Spleen. Bentham Science Publishers Ltd; 2011. pp. 20-36.

[2] Hosey RG, Mattacola CG, Kriss V, Armsey T, Quarles JD, Jagger J. Ultrasound assessment of spleen size in collegiate athletes. Br J Sports Med. 2006;40(3):251-54

[3] Chow KU, Luxembourg B, Seifried E, Bonig H. Spleen size is significantly influenced by body height and sex: Establishment of normal values for spleen size at us with a cohort of 1200 healthy individuals. Radiology. 2016;279(1):306-13.

[4] Özdikici M. The relationship between splenic length in healthy children from the Eastern Anatolia Region and sex, age, body height and weight. J Ultrason. 2018;18(72):05-08

[5] Tekle Y, Hiware S, Mohammed H. Normal spleen size in relation to weight of adult population in the northwest Ethiopia region: A radiological study. Asian $\mathrm{J}$ Med Res. 2019;8(1):05-08

[6] Arkles LB, Gill GD, Molan MP. A palpable spleen is not necessarily enlarged or pathological. Med J Aust. 1986;145(1):15-17

[7] van Beek EJR, Kuhl C, Anzai Y, Desmond P, Ehman RL, Gong Q, et al. Value of MRI in medicine: More than just another test? Vol. 49, Journal of Magnetic Resonance Imaging. John Wiley and Sons Inc.; 2019. pp. e14-25.

[8] Ibrahim R, Samian S, Mazli M, Amrizal M, Aljunid SM. Cost of Magnetic Resonance Imaging (MRI) and Computed Tomography (CT) scan in UKMMC. BMC Health Serv Res. 2012;12(S1):P11.

[9] Pearce MS, Salotti JA, Little MP, McHugh K, Lee C, Kim KP, et al. Radiation exposure from CT scans in childhood and subsequent risk of leukaemia and brain tumours: A retrospective cohort study. Lancet. 2012;380(9840):499-505.

[10] Power SP, Moloney F, Twomey M, James K, O'Connor OJ, Maher MM. Computed tomography and patient risk: Facts, perceptions and uncertainties. World J Radiol. 2016:8(12):902.

[11] Debongnie JC, Pauls C, Fievez M, Wibin E. Prospective evaluation of the diagnostic accuracy of liver ultrasonography. Gut. 1981;22(2):130-35

[12] Hernaez R, Lazo M, Bonekamp S, Kamel I, Brancati FL, Guallar E, et al. Diagnostic accuracy and reliability of ultrasonography for the detection of fatty liver: A meta-analysis. Hepatology. 2011 Sep 2;54(3):1082-90.

[13] Dick R. Text book of Radiology and Imaging-Google Scholar. London: Churchill Livingstone. 1998. Pp. 981-1028.

[14] Klühs L, Teichgräber UKM, Schneider U, Ludwig WD, Dörken B, Benter T. Genauigkeit der sonographischen milzgewichtsbestimmung am lebenden im vergleich zum pathologischen korrelat. RoFo Fortschritte auf dem Gebiet der Rontgenstrahlen und der Bildgeb Verfahren. 2003;175(4):532-35.
[15] Frank K, Linhart $P$, Kortsik $C$, Wohlenberg $H$. Sonographische Milzgrössenbestimmung: Normalmasse beim milzgesunden Erwachsenen. Ultraschall Med. 1986;7(3):134-37.

[16] Lamb PM, Lund A, Kanagasabay RR, Martin A, Webb JAW, Reznek RH. Spleen size: How well do linear ultrasound measurements correlate with three dimensional CT volume assessments? Br J Radiol. 2002;75(895):573-77.

[17] Ehimwenma O, Tagbo M. Determination of normal dimension of the spleen by ultrasound in an endemic tropical environment. Niger Med J. 2011;52(3):198.

[18] Crosby $\mathrm{WH}$. Hematopoiesis in the human spleen. Arch Intern Med. 1983;143(7):1321-22.

[19] Chowdhury Al, Sultana SZ, Mannan S. Morphometric study of splenic volume in Bangladeshi cadaver. Mymensingh Med J. 2012;21(3):445-49.

[20] Mohammadi S, Hedjazi A, Sajjadian M, Kebriaei SMM, Naser Ghrobi N, Yaghmae A, et al. Morphometric study of spleen in iranian cadavers from Razavi-Khorasan Province. Bangladesh Med Res Counc Bull. 2016;42(2):61-66.

21] Caglar V, Kumral B, Uygur R, Alkoc OA, Ozen OA, Demirel H. Study of volume, weight and size of normal pancreas, spleen and kidney in adults autopsies. Forensic Med Anat Res. 2014;02(03):63-69.

[22] Kaneko J, Sugawara Y, Matsui Y, Ohkubo T, Makuuchi M. Normal splenic volume in adults by computed tomography. Hepatogastroenterology. 2002;49(48):1726-27.

[23] Srisaijakul S, Prapaisilp P, Laorratkul N. Normal Splenic Volume Assessment on CT in 426 Adults. Siriraj Med J. 2012;64(2):43-46.

[24] Harris A, Kamishima T, Hao HY, Kato F, Omatsu T, Onodera Y, et al. Splenic volume measurements on computed tomography utilizing automatically contouring software and its relationship with age, gender, and anthropometric parameters. Eur J Radiol. 2010;75(1):e97-101.

[25] Prassopoulos P, Daskalogiannaki M, Raissaki M, Hatjidakis A, Gourtsoyiannis N. Determination of normal splenic volume on computed tomography in relation to age, gender and body habitus. Eur Radiol. 1997;7(2):246-48.

[26] Sarac K, Kutlu R, Yakinci C, Durmaz Y, Baysal T, Özgen Ü. Sonographic evaluation of liver and spleen size in school-age children. Turkish $\mathrm{J}$ Med Sci. 2000;30(2):187-90.

[27] Capaccioli L, Stecco A, Vanzi E, Brizzi E. Ultrasonographic study on the growth and dimensions of healthy children and adults organs. Ital J Anat Embryol. 2000;105(1):01-50.

[28] Megremis SD, Vlachonikolis IG, Tsilimigaki AM. Spleen length in childhood with us: normal values based on age, sex, and somatometric parameters. Radiology. 2004:231(1):129-34.

[29] Singhal R, Patel SM, Agrawal M, Rupareliya S, Patel D, Shrivastava A Sonographic measurement of spleen in relation to age: A prospective study in adult Gujarati population. Indian J Anat. 2018;7(4):412-17.

[30] Arora N, Sharma PK, Sahai A, Singh R. Sonographic measurements of the spleen in relation to age; a prospective study in North Indian adults. J Anat Soc India. 2010;59(2):177-81.

[31] Loftus WK, Metreweli C. Ultrasound assessment of mild splenomegaly: Spleen/ kidney ratio. Pediatr Radiol. 1998;28(2):98-100.

[32] Chakraborti S, Saha N, Debbarma B, Das S, Leishram D. Normal spleen length by ultrasonography in adults of Tripura. IOSR J Dent Med Sci e-ISSN. 2016;15(1):55-60.

[33] Sharma K, Lamichhane P, Sharma B, Sharma B. Sonographic measurement of spleen in relation to age: A prospective study among adult nepalese people in western Nepal. J Gandaki Med Coll. 2017;10(1):11-16.

[34] Talukder S, Islam N, Joarder N, Rahman R, Debnath J, Sabuj SS. Sonographic Determination of Normal Spleen Weight among Adults at Barishal District in Bangladesh Article History Abstract. Int J Innov Res. 2018;3(3):90-93.

[35] Khan SA, Yasmeen S, Adil SO, Huda F. Sonographic evaluation of normal liver, spleen, and renal parameters in adult population: A multicenter study Hatem Adil. J Coll Physicians Surg Pak. 2018;28(11):834-39.

\section{PARTICULARS OF CONTRIBUTORS:}

1. Assistant Professor, Department of Anatomy, Pt. Jawahar Lal Nehru Memorial Medical College, Raipur, Chhattisgarh, India.

2. Professor, Department of Anatomy, Pt. Jawahar Lal Nehru Memorial Medical College, Raipur, Chhattisgarh, India.

3. Professor, Department of Radiodiagnosis, Pt. Jawahar Lal Nehru Memorial Medical College, Raipur, Chhattisgarh, India.

NAME, ADDRESS, E-MAIL ID OF THE CORRESPONDING AUTHOR:

Kushal Chakraborty,

567, Priyadarshini Nagar, Ring Road 1, Raipur, Chhattisgarh, India

E-mail: drkushalchakraborty@gmail.com

\section{AUTHOR DECLARATION}

- Financial or Other Competing Interests: None

- Was Ethics Committee Approval obtained for this study? Yes

- Was informed consent obtained from the subjects involved in the study? Yes

- For any images presented appropriate consent has been obtained from the subjects. NA
PLAGIARISM CHECKING METHODS: [Jain Het al.]

- Plagiarism X-checker: Feb 11, 2021

- Manual Googling: May 26, 2021

- iThenticate Software: Jun 22, 2021 (7\%)
ETYMOLOGY: Author Origin Date of Peer Review: Mar 26, 2021

Date of Acceptance: May 27, 2021 Date of Publishing: Oct 01, 2021 